\title{
Earnings Management Through Foreign Currency Transactions on Companies Listed on Indonesia Stock Exchange
}

\author{
Yulius Jogi Christiawan ${ }^{1 *}$ and I Made Narsa $^{2}$ \\ ${ }^{1}$ Department of Accounting, Faculty of Business and Economics, Petra Christian University. \\ Jl. Siwalankerto 121-131, Surabaya 60236, Indonesia \\ ${ }^{2}$ Department of Accounting, Faculty of Economy and Business, Airlangga University, \\ Jl. Airlangga 4-6, Surabaya 60286, Indonesia
}

\begin{abstract}
This research aims to examine whether the condition of Rupiah currency, the magnitude of monetary liabilities in foreign currencies, and the condition of operating profit affects the management's aggressiveness to perform earnings management through foreign exchange gain or loss (FEGL) post. This research was conducted on 258 companies listed on the BEI in 2009 to 2015 . This research was successfully proved on earnings management through foreign currency transactions phenomenon for several conditions. First, in the condition of Rupiah appreciation, the managers that have monetary liabilities in foreign currency are less than the monetary assets in foreign currency are more daring to make earnings management through FEGL post than companies that have monetary liabilities in foreign currency greater than monetary assets in foreign currency. Second, managers of companies that decreasing in operating profit, more daring to make earnings management through FEGL post than companies that experience an increase in operating profit. Under the depreciation of the Rupiah, the managers of companies with monetary liabilities in foreign currency are less than monetary assets in foreign currency, are more aggressive to perform earnings than the managers of companies who have monetary liabilities denominated in foreign currency greater than the monetary assets in foreign currency.
\end{abstract}

Keywords: Depreciation of the Rupiah, foreign exchange gain or losses, monetary liabilities, operating profit, IDR currency.

\section{Introduction}

The earnings management phenomenon has attracted researchers since Healy [1] proved that managers do earnings management to maximize their bonuses. There are three hypotheses in earning management which explained the opportunistic behavior from the positive accounting theory. The three hypotheses are (i) the bonus plan hypothesis, (ii) the debt to equity hypothesis, and (iii) the political cost hypothesis. Some researchers have managed to prove earnings management behavior in the context of the bonus plan hypothesis [2]. Other researchers have succeeded in proving earnings management behavior concerning debt covenant violations [3-5]. In a political context, the company is proven to

\footnotetext{
* Corresponding author: yulius@ peter.petra.ac.id
} 
carry out earnings management to follow changes in tax rates [6]. Generally, researchers see earnings management as an act of making accounting policy choices. This action is detected by abnormal proxy accrual or discretionary accrual.

Besides making accounting policy options, earnings management can be done through real activities. Every post in the income statement which determines the value of net income can be an object for earnings management. Earnings management in the form of income maximization can be done by recognizing income early [7], increasing sales by giving discounts [8], giving cash incentives to the salesman [9] or selling fixed assets [10]. Increasing profits has also been made by reducing non-operating expenses [11], reducing the cost of good sold and discretionary expenses [8], reducing the allowance of uncollectible accounts [12], reduce advertising expenses [13] and R\&D expenses [14]. Managers also use almost all posts in the income statement to influence earnings achievement. These posts include income and sales, general and administrative expenses, as well as non-operational profit and loss [15].

The theoretical explanation of earnings management generally uses Agency Theory. However, several other researchers use Prospect Theory to explain the phenomenon of earnings management. Prospect Theory is used to explain why earnings management is performed to avoid profit decline instead of avoiding loss reporting [16]. Companies are proven to seek risk by doing income-decreasing when debt is restructured or renegotiated because the waiver is rejected [17]. Other empirical evidence shows that, when operational performance is poor, the company carries out an income-increasing strategy, and when operational performance is extremely poor, the company seeks risk by carrying out a "big bath" strategy [18].

In contrast to previous studies, this study aims to look at the phenomenon of earnings management that is allegedly carried out through foreign exchange gains or losses (FEGL). The value of FEGL can be influenced by management in real terms to achieve specific profit goals. This study also aims to obtain empirical evidence of Prospect Theory in the phenomenon of earnings management. To achieve these objectives, this study hypothesizes three conditions that are considered to influence earnings management actions through the FEGL post. The three conditions are the condition of the rupiah, conditions of pressure on monetary liabilities and conditions of operating profit.

The FEGL phenomenon is interesting to study because FEGL puts particular pressure on companies in Indonesia. For example, in 2013 the Rupiah (IDR) depreciated $26.0 \%$ against USD (www.bi.go.id), the depreciation of the Rupiah forces the companies that have monetary liabilities in foreign currencies, especially USD, to recognize exchange losses on the income statement as stipulated in PSAK No. 10 [19].

Under conditions of depreciation of Rupiah, management can increase foreign exchange gains by real activities through enlarging the monetary assets in foreign currencies, for example, increasing cash and cash equivalents in foreign currency or increasing export sales. Management can also reduce foreign exchange losses by paying off foreign currency monetary liabilities or reducing operating expenses in foreign currencies. Earnings management in the FEGL post will further affect net income because net income in the presentation format of the income statement is calculated from operating income less "Other Income and Expenses," and the FEGL post is part of the "Other Income and Expenses" component.

Based on the background above, this study aims to obtain empirical evidence whether the condition of the Rupiah (Rp - IDR), the magnitude of monetary liabilities in foreign currencies (MML), and the condition of operating profit (OP) affect the management's aggressiveness to manage earnings through the FEGL post. This research is a proof for the Prospect Theory in explaining the problem of earnings management behavior in other conditions, namely: the presence of net monetary liabilities in foreign currencies pressures 
both in conditions of depreciation and appreciation of the Rupiah and conditions of decline in operating profit. Methodologically, this study proposes a new measurement model to detect earnings management through the FEGL post.

\section{Literature review and hypotheses development}

\subsection{Prospect theory}

Prospect Theory underlies the conceptual development of this research. Kahneman and Tversky [20] look at behavior in decision making. Prospect Theory explains that people give lower weight outcomes that are still possible compared to outcomes that are certain to be obtained (certainty effect). This tendency contributes to the risk aversion behavior in decision choices that are beneficial (gain) and risk-seeking for adverse decision choices (loss). Decision-makers irrationally or emotionally see situations of gain and loss in different ways. An adverse situation (loss) brings a more significant emotional impact than a favorable situation (gain). If someone frames an outcome as a loss, then it assumes to accept a higher risk than the same outcome but using gain framing.

\subsection{Earnings management through the FEGL post}

Management can manage earnings by utilizing PSAK 10. For example, when the depreciation of Rupiah, management can increase foreign exchange gains by enlarging the post of monetary assets in foreign currencies or reducing foreign exchange losses by paying off the monetary liabilities in the foreign currency more quickly. FEGL can also be affected by influencing foreign exchange revenue and expense transactions and derivative instrument transactions to hedge cash flows due to fluctuations in foreign currencies. This real activity is used to make the model normal FEGL. The FEGL model was developed with the thought that management can influence the FEGL by enlarging or reducing the assets and liabilities in foreign currency, revenue and expense transactions in foreign currencies, and instrument transactions for derivative hedging activities on fluctuations in currency exchange rates.

Earnings management through the FEGL post (EMFEGL) in this study was proxied by using abnormal FEGL. The absolute value of abnormal FEGL is used as a variable measure of management's courage to manage earnings through the FEGL post (ABSEMFEGL). The higher ABSEMFEGL score indicates, the more courage management takes management actions to influence FEGL. Abnormal FEGL is calculated by the following Equation:

Abnormal FEGL $_{\text {it }}=$ Total FEGL Fit - Normal FEGL $_{\text {it }}$

\subsection{Previous empirical research review}

Some researchers investigate whether currency conditions or exchange rates are associated with accounting variables. The stock market uses the information on foreign exchange gains and losses when valuing stock securities as well as other earnings information. The stock market also uses unrealized translation gain and losses information in the equity section when assessing stock securities as the other components of earnings [21]. Hsiao and Han [22] prove the existence of a positive association between currency exchange rate volatility and firm value. These studies show that the foreign exchange gain or loss is one of the information considered in investment decisions by investors so that it can motivate management to conduct earnings management through the FEGL post. This research extends the previous research in two ways. First, in contrast to previous research that looks at the response of users of financial statements to currency conditions, this study looks at 
the side of management's behavior as a provider of financial information. Second, this study links the depreciation and appreciation conditions of currencies with earnings management.

The relationship between financial pressures and earnings management can be explained through the debt to equity hypothesis. The greater the ratio of debt to equity, managers will choose accounting methods that have the effect of increasing profits [4]. Managers are proven to manipulate accruals three months consecutively to increase profits [3] and increase profits three months before a debt covenant violation [5]. Companies are also proven to perform earnings management in the form of income-increasing accruals when experiencing financial pressure so that the company gets forgiveness (waiver) from creditors and performs income-decreasing when companies restructure their debt or debt is renegotiated because their waiver is rejected by creditors [17]. This study extends previous research by looking at how the loss situation due to pressure on monetary liabilities of foreign currencies will affect the courage of management to manage earnings through the FEGL post.

Research conducted after Healy [1] provides consistent evidence that earnings management aims to keep profits positive and avoid earnings decline. Companies do earnings management to avoid decreasing profits and losses [23]. Research in Australia [24], in South Africa [25] and Malaysia [26] show that companies carry out earnings management to avoid decreased earnings. Fujiyama et al. [27] found that companies in Finland, Germany, Italy, and Japan carried out earnings management to avoid losses while companies in Israel and America carried out earnings management to avoid profit decline. When operational performance is poor, companies tend to do income-increasing strategies, and when operational performance is very bad, some companies carry out a "big bath" strategy [18]. In contrast to previous research, this study wants to prove the prospect theory to see whether a risky situation due to a decrease in operating profit will affect the courage of management to manage earnings through the FEGL post.

\subsection{Hypothesis development}

Earnings management through FEGL post is a decision that management can choose. Three variables are suspected to influence the courage of management to do earnings management through FEGL post. The three variables are pressure on net monetary liabilities in foreign currencies, Rupiah exchange rate conditions, and operating profit conditions.

When the rupiah exchange rate depreciates against USD, companies that have monetary liabilities in foreign currencies greater than monetary assets in foreign currencies are in a loss position. They have to recognize the presence of foreign exchange losses causing the probability of not achieving the profit target. Besides, monetary liabilities of foreign currencies originating from bank loan posts also require companies to comply with financial ratios that must be maintained throughout the loan period. If the financial ratios are related to net income, then that ratio may not be achieved. Conversely, companies that have monetary liabilities in foreign currencies that are smaller than monetary assets in foreign currencies are in a position of gain. Prospect Theory explains that the pain when in a loss situation will be responded to more than when in a position of gain, so decisionmakers tend to look for risk when in a position of loss. When someone frames an outcome as a loss, then he assumes accepting a higher risk than the same outcome but uses gain framing. In this research, risk-seeking behavior is manifested in the form of more daring to do earnings management through the FEGL post. When the Rupiah depreciates, monetary liabilities in foreign currencies greater than monetary assets in foreign currencies are considered to be riskier than monetary liabilities in foreign currencies which are smaller than monetary assets in foreign currencies, so the first hypotheses are proposed as follow: 
H1: When the Rupiah depreciates against USD, the management of companies that have monetary liabilities higher than monetary assets in foreign currencies, is more courageous to manage earnings through FEGL post than the management that have monetary liabilities smaller than a monetary asset in foreign currencies.

When the Rupiah appreciates, monetary liabilities of foreign currency smaller than monetary assets of foreign currencies are considered to be riskier than monetary liabilities in foreign currencies greater than monetary assets in foreign currencies, and the second hypotheses are as follow:

H2: When Rupiah appreciates against USD, the management of companies that have monetary liabilities smaller than monetary assets in foreign currencies are more courageous to manage earnings through FEGL post than the management of companies that have monetary liabilities larger than monetary assets in foreign currencies.

A loss position also occurs when a decline in operating profit. Conversely, an increase in operating profit is considered a gain for company managers. The pain due to the decrease in operating profit is greater than the pleasure from the increase in operating profit, although in the same amount. A decrease in operating profit compared to the previous year could cause a lower probability of meeting the current year's net profit target. Based on this explanation, this study hypothesizes:

H3: Management of companies that experience a decline in operating profit is more daring to do earnings management through the FEGL post than the management that has increased operating profit.

\section{Research methodology}

This research is a correlational or relational study as it is designed to find out whether one or more variables have an association with other output variables [28]. The formulation below expresses the multiple regression model to examine the relationships between the variables.

$$
\begin{aligned}
\mathrm{ABSEMFEGL}_{\mathrm{it}}= & \beta_{0}+\beta_{1} \mathrm{MML}_{\mathrm{it}}+\beta_{2} \mathrm{OP}_{\mathrm{it}}+\beta_{3} \mathrm{RP}_{\mathrm{it}}+\beta_{4} \mathrm{TA}_{\mathrm{it}}+\beta_{5} \mathrm{LEV}_{\mathrm{it}}+\beta_{6} \mathrm{ROA}_{\mathrm{it}}+\beta_{7} \mathrm{D} 1_{\text {it }}+ \\
& \beta_{8} \mathrm{D} 2_{\mathrm{it}}+\beta_{9} \mathrm{D} 3_{\mathrm{it}}+\beta_{10} \mathrm{D} 1_{\text {it }} \times \mathrm{MML}_{\mathrm{it}}+\beta_{11} \mathrm{D} 3_{\mathrm{it}} \times \mathrm{MML}_{\mathrm{it}}+\beta_{12} \mathrm{D} 1_{\mathrm{it}} \times \mathrm{D} 3_{\mathrm{it}} \times \\
& \mathrm{MML}_{\mathrm{it}}+\beta_{13} \mathrm{D} 2_{\mathrm{it}} \times \mathrm{OP}_{\mathrm{it}}+\varepsilon_{\mathrm{it}}
\end{aligned}
$$

ABSEMFEGL is an earnings management action through the FEGL post. MML is a condition of foreign currency monetary liabilities as measured by the ratio between net foreign currency monetary liabilities and the average total assets. OP is the change in the company's operating profit. D1, D2, and D3 are dummy variables that indicate the conditions of monetary liability pressures, operating profit conditions, and the condition of the Rupiah that is thought to influence earnings management behavior through the exchange rate difference. Dummy variable "D1" is a variable to categorize the gain or loss situation caused by the pressure of monetary liabilities. The point of reference in this situation is a situation of no gain or no loss or a situation where monetary liabilities (ML) in foreign currencies are equal to the number of monetary assets (MA). Variable D1 is given a score of 1 for companies with an ML higher than MA and a score of 0 for companies with an ML smaller than MA. Dummy variable "D2" is a variable to categorize the gain or loss situation caused by operational profit conditions. The reference point for this situation is a situation of no gain or no loss or a situation where the current year's operating profit ( $\left.O P_{i t}\right)$ is the same as the previous year's operating profit $\left(\mathrm{OP}_{\mathrm{it}-1}\right)$. The $\mathrm{D} 2$ variable is given a score of 1 for companies with $\mathrm{OP}_{\text {it-1 }}$ greater than $\mathrm{OP}_{\mathrm{it}}$ or companies with $\mathrm{OP}_{\mathrm{it}}$ smaller than zero and a score of 0 for companies with $\mathrm{OP}_{\text {it-1 }}$ smaller than $\mathrm{OP}_{\text {it }}$, or companies with $\mathrm{OP}_{\text {it }}$ greater 
than zero. The dummy variable "D3" is a variable to categorize the appreciation and depreciation of the Rupiah. The D3 variable is given a score of 1 for the appreciation situation and a score of 0 for depreciation.

This study uses four other variables, namely: Rupiah Condition (RP), total assets (TA), Leverage (LEV), and Profitability (ROA). The condition of the rupiah is the strengthening or weakening of the rupiah exchange rate against USD, which is calculated by the ratio of the increase or decrease in the middle exchange rate of the Rupiah against USD to the middle exchange rate at the beginning of the year. Variable Total Assets (TA) is the average total amount of assets owned by a company. Leverage variable (LEV) is the ratio between total long-term and short-term liabilities and the average total assets. The profitability variable is the ratio of net income to the average total assets of the current year.

This research was conducted on all public companies listed on the Stock Exchange except those from the financial industry. The year of observation was 2009-2015. Hypothesis testing is done by t-test. Based on the hypothesis formulation set and the equation model to test the hypothesis in Equation 2, then:

Hypothesis 1 is proven when:

$\beta_{1}<0,\left(\beta_{1}+\beta_{10}\right)>0$ and $\left|\beta_{1}+\beta_{10}\right|>\left|\beta_{1}\right|$

Hypothesis 2 is proven when:

$\left(\beta_{1}+\beta_{11}\right)<0,\left(\beta_{1}+\beta_{10}+\beta_{11}+\beta_{12}\right)>0$ and $\left|\beta_{1}+\beta_{11}\right|>\left|\beta_{1}+\beta_{10}+\beta_{11}+\beta_{12}\right|$

Hypothesis 3 is proven when:

$\left(\beta_{2}+\beta_{13}\right)<0, \beta_{2}>0$ and $\left|\beta_{2}+\beta_{13}\right|>\left|\beta_{2}\right|$

All multiple regression analyses were performed using statistic software.

\section{Result and discussion}

This study uses specific criteria to select research samples. Based on the established criteria, there are 203 companies with 1420 observed data from 2009 to 2015. Based on Table 1, there are several phenomena of financial reporting conducted by companies. First, there are 93 financial statements from 29 companies that do not present or disclose the FEGL, but disclose foreign currency monetary assets and liabilities in their financial statements, and 114 financial statements from 41 companies that do not disclose foreign currency monetary assets and liabilities, but presents or discloses the FEGL. This phenomenon shows that these companies have transactions in foreign currencies, but they are inadequate in the presentation and disclosure in their financial statements. These companies should disclose in full both the foreign exchange gains and losses and the monetary assets and liabilities in foreign currencies. Secondly, there were 47 companies that were not found in the 2008 financial statements either on the IDX website or the company website. It is not known for certain why the 47 companies' 2008 financial statements are not on the IDX website and the company's website. 
Table 1. Sample frame

\begin{tabular}{lr}
\hline \multicolumn{1}{c}{ Sampel Criteria } & $\begin{array}{r}\text { Number of } \\
\text { companies }\end{array}$ \\
\hline Companies listed on the IDX based on annual report 2016 (IDX, 2016) & 537 Companies \\
\hline Minus: Banks, Financial Institutions and Securities Companies & 97 Companies \\
Companies registered between 2009 to 2016 97 companies & 132 Companies \\
\hline Number of companies sample size & 308 companies \\
\hline Number of years of observation (2009 to 2015) & 7 yr \\
\hline The total sample of financial statement data observed & 2156 \\
\hline Minus: Financial Statements in USD (56 companies.) & 269 \\
Fiscal year other than December 31 (5 companies.) & 26 \\
Financial Statements are incomplete or not found on the Web (27 companies.) & 43 \\
Financial Statements do not disclose MA, ML, and FEGL (30 companies) & 136 \\
Financial Statements do not disclose FEGL only (29 companies.) & 93 \\
The Financial Statements do not disclose MA and ML only (41 companies.) & 114 \\
MA and ML are presented in foreign currencies (3 companies.) & 8 \\
Financial Statement 2008 was not found on the IDX Web (47 companies) & 47 \\
& \\
\hline The sample size complies with the criteria (203 companies.) & 1420 \\
\hline
\end{tabular}

Source: researcher

\subsection{Variable descriptive analysis for testing the hypotheses}

Table 2. demonstrated the descriptive analysis result of each variable used to examine the hypotheses.

Table 2. Variable descriptive analysis result

\begin{tabular}{|c|c|c|c|c|c|}
\hline & $\mathbf{N}$ & Min & Max & Average & Deviation Std. \\
\hline ABSEMFEGL & 1420 & 0.00 & 0.20 & 0.0079 & 0.01364 \\
\hline EMFEGL & 1420 & -0.14 & 0.20 & -0.0001 & 0.01575 \\
\hline MML & 1420 & -1.14 & 3.25 & 0.1105 & 0.29055 \\
\hline $\mathrm{OP}$ & 1420 & -0.58 & 0.69 & 0.0091 & 0.07285 \\
\hline RP & 1420 & -0.26 & 0.14 & -0.0401 & 0.11404 \\
\hline TA & 1420 & 9.50 & 240731.00 & 6094.7895 & 16879.84614 \\
\hline LEV & 1420 & 0.00 & 4.03 & 0.2736 & 0.31723 \\
\hline ROA & 1420 & -1.23 & 0.97 & 0.0485 & 0.12741 \\
\hline ABSEMFEGL & & & & & \\
\hline Appreciation of $14.20 \%, 2009$ & 175 & 0.00 & 0.07 & 0.0117 & 0.01385 \\
\hline Appreciation of $4.40 \%, 2010$ & 235 & 0.00 & 0.05 & 0.0052 & 0.00700 \\
\hline Depreciation of $0.9 \%, 2011$ & 222 & 0.00 & 0.03 & 0.0037 & 0.00484 \\
\hline Depreciation of $2.1 \%, 2014$ & 199 & 0.00 & 0.05 & 0.0043 & 0.00680 \\
\hline Depreciation of $6.6 \%, 2012$ & 202 & 0.00 & 0.10 & 0.0063 & 0.00973 \\
\hline Depreciation of $10.90 \%, 2015$ & 187 & 0.00 & 0.06 & 0.0087 & 0.01000 \\
\hline Depreciation of $26.00 \%, 2013$ & 200 & 0.00 & 0.20 & 0.0168 & 0.02654 \\
\hline
\end{tabular}

Sumber: Statistic software result

Note: EMFEGL = earnings management through the FEGL post, RP = percentage increase (decrease) in the Rupiah exchange rate against USD at the end of the year compared to the beginning of the year, $\mathrm{MML}=$ pressure on monetary liabilities, $\mathrm{OP}=$ Operating Profit conditions, $\mathrm{TA}=$ average total assets, $\mathrm{LEV}=$ ratio of total debt to average total assets, $\mathrm{ROA}=$ ratio of net income to average total assets .

Table 2. shows that the average difference between the actual FEGL and the normal FEGL reported by the company is $0.79 \%$ of the average of their total assets. The higher ABSEMFEGL number shows, the bolder companies do earnings management through the FEGL post. The highest ABSEMFEGL score occurs when Rupiah's appreciation and 
depreciation is the highest. When the rupiah appreciated $14.4 \%$, the ABSEMFEGL score was $1.17 \%$, and when the Rupiah depreciated $26 \%$, the ABSEMFEGL score was $1.68 \%$. This shows that companies in situations of high rupiah appreciation or depreciation are more willing to manage earnings through the FEGL post compared to situations of low rupiah depreciation or appreciation. The EMFEGL average for all observations was negative 0.000 1, which means that the average sample data had an actual FEGL of $0.01 \%$ less than the average of their total assets.

The average sample company has net foreign currency monetary liabilities of $11.05 \%$ of its average total assets. The largest value of the variable foreign currency net monetary liabilities is $325 \%$ or 3.25 times the average total assets. Companies with net liabilities that are greater than the total assets can be accounted for with certainty that they have negative equity or experience capital deficiency. The minimum value is negative at 1.14 . Negative numbers indicate that the amount of monetary liabilities is smaller than the monetary assets of foreign currencies. A minimum negative value of 1.14 means that the total net monetary assets of the company are $114 \%$ or 1.14 times the average total asset. The average sample company experienced an increase in operating profit by $0.91 \%$ from the average of their total assets.

The entire sample company has an average total asset of IDR $6094.79 \times 10^{9}$. For hypothesis testing, this variable unit is transformed to billion per one million. The average sample company had a total loan of $27.36 \%$ of its average total assets. The average sample company has a net profit of $4.85 \%$ of the average of their total assets.

The variable condition of the Rupiah currency is the condition of strengthening or weakening of the Rupiah exchange rate against USD in the form of a percentage increase or decrease in the average exchange rate of the Rupiah against USD. Table 3. shows the conversion rate of USD to IDR, and it can be seen that IDR appreciated against USD in 2009 to 2010, and depreciated from 2011 to 2015.

Table 3. Exchange rate of IDR against USD

\begin{tabular}{cccrr}
\hline Year & $\begin{array}{c}\text { The middle rate at } \\
\text { the beginning of the } \\
\text { year }\end{array}$ & $\begin{array}{c}\text { Year-end middle rate } \\
\text { (IDR / 1 USD) }\end{array}$ & \multicolumn{2}{c}{ Decrease (Increase) } \\
\cline { 4 - 5 } & (IDR / 1 USD) & & & \% \\
\hline 2009 & 10950 & 9400 & 1550 & 14.2 \\
2010 & 9400 & 8991 & 409 & 4.4 \\
2011 & 8991 & 9068 & -77 & -0.9 \\
2012 & 9068 & 9670 & -602 & -6.6 \\
2013 & 9670 & 12189 & -2519 & -26.0 \\
2014 & 12189 & 12440 & -251 & -2.1 \\
2015 & 12440 & 13795 & -1355 & -10.9 \\
\hline
\end{tabular}

Source: www.bi.go.id/id/moneter/informasi-kurs/transaksi-bi/default.aspx

\subsection{Hypothesis testing results}

Based on the significance of the $\mathrm{F}$ value in Table 4 shows that the regression model meets the goodness of fit with a significance level of $1 \%$. Model 1 and model 2 each have an adjusted R Square of 0.152 and 0.234 , which means that all independent variables can explain for $15.2 \%$ and $23.4 \%$ changes in the dependent variable of earnings management through the FEGL (ABSEMFEGL) post. Model 2 has an adjusted R Square that is larger than model 1 because model 2 considers the gain and loss situations caused by the conditions of MML, RP, and OP.

Model 2 in Table 4 presents hypothesis testing. Hypothesis 1 explains the association between MML and ABSEMFEGL by considering the gain and loss conditions due to the condition of MML in the depreciation situation of Rupiah. Based on Table 4, it is known 
that $\beta_{1}$ is equal to -0.029 , and $\beta_{10}$ is equal to 0.049 , so that $\left(\beta_{1}+\beta_{10}\right)$ is equal to 0.020 . These results indicate that the slope of the line at the loss position $\left(\beta_{1}+\beta_{10}\right)$ is more slightly than the slope of the line at the gain position $\beta_{1}$, so it can be concluded that hypothesis 1 is not supported. In the rupiah depreciation situation, companies in the position of gain, because they have monetary liabilities of foreign currencies, are smaller than monetary assets of foreign currencies, actually they are more aggresive to manage earnings through FEGL post compared to companies that are in a position of loss because they have monetary liabilities of foreign currency greater than monetary assets of foreign currencies. Hypothesis 2 explains the association between MML and ABSEMFEGL by considering the gain and loss conditions due to the condition of MML in the Rupiah appreciation situation. Based on table 4 , it is known that $\beta_{1}$ is equal to $-0.029, \beta_{10}$ is equal to $0.049, \beta_{11}$ is equal to 0.011 and $\beta_{12}$ is equal to -0.020 , so that $\left(\beta_{1}+\beta_{11}\right)$ is equal to -0.018 and $\left(\beta_{1}+\beta_{10}+\beta_{11}+\right.$ $\beta_{12}$ ) is equal to 0.011 . Based on this score it can be seen that the slope of the line at the loss position $\left(\beta_{1}+\beta_{11}\right)$ is steeper than the slope of the line at the gain position $\left(\beta_{1}+\beta_{10}+\beta_{11}+\right.$ $\beta_{12}$ ), so hypothesis 2 is supported. In a situation of Rupiah appreciation, a company in a loss position because it has monetary liabilities in foreign currency is smaller than monetary assets of foreign currencies more aggresive to manage earnings through the FEGL post compared to companies that are in a position of gain because they have monetary liabilities in foreign currency greater than monetary assets in foreign currency.

Hypothesis 3 describes the association between OP and ABSEMFEGL by considering the gain or loss situation caused by operating profit conditions. Based on model 2 in Table 4 , it can be seen that $\beta_{2}$ is equal to 0.014 , and $\beta_{13}$ is equal to -0.035 , so that $\left(\beta_{2}+\beta_{13}\right)$ is equal to - 0.021. Based on this score, it appears that the slope of the line at the loss position $\left(\beta_{2}+\beta_{13}\right)$ is steeper than the slope of the line at the gain position $\left(\beta_{2}\right)$, so it can be concluded that hypothesis 3 is supported. Companies at a loss due to a decrease in the OP are more aggresive to do earnings management through the FEGL post than companies at a position of gain due to OP increases.

Table 4. Model Fitness and Hypotheses Testing $(\mathrm{N}=1420)$

\begin{tabular}{|c|c|c|c|c|c|c|c|}
\hline & & Mode & & & & Model 2 & \\
\hline & B & SE & $t-s t$ & & B & SE & t - stat \\
\hline Constant & 0.005 & 0.001 & 9.952 & *** $*$ & -0.001 & 0.001 & -0.892 \\
\hline MML & 0.013 & 0.001 & 9.147 & $* * *$ & -0.029 & 0.005 & $-5.551^{* * *}$ \\
\hline OP & 0.007 & 0.005 & 1.423 & & 0.014 & 0.007 & $2.088^{* *}$ \\
\hline $\mathrm{RP}$ & -0.022 & 0.003 & -7.559 & $* * *$ & -0.042 & 0.004 & $-10.738^{\text {*** }}$ \\
\hline TA per 1 mill. & -0.045 & 0.020 & -2.268 & $* *$ & -0.028 & 0.019 & -1.496 \\
\hline LEV & 0.003 & 0.001 & 2.367 & $\begin{array}{l}* * \\
* *\end{array}$ & $\begin{array}{r}-0.028 \\
0.002\end{array}$ & $\begin{array}{l}0.001 \\
0.003\end{array}$ & $1.600_{* *}$ \\
\hline ROA & -0.006 & 0.003 & -2.180 & $* *$ & -0.006 & $\begin{array}{l}0.003 \\
0.001\end{array}$ & $-2.141_{* *}$ \\
\hline $\begin{array}{l}\text { D1 } \\
\text { D2 }\end{array}$ & & & & & 0.002 & $\begin{array}{l}0.001 \\
0.001\end{array}$ & 2.122 \\
\hline D3 & & & & & -0.001 & 0.001 & $-0.765 * * *$ \\
\hline D1xMML & & & & & 0.008 & 0.006 & $7.609_{* * *}$ \\
\hline D3xMML & & & & & 0.049 & 0.011 & 8.892 \\
\hline D1xD3xMML & & & & & 0.011 & 0.011 & $1.054 *$ \\
\hline $\mathrm{D} 2 \mathrm{xOP}$ & & & & & -0.020 & 0.011 & $-1.775 * *$ \\
\hline & & & & & -0.035 & & -3.043 \\
\hline R Square & & & & 0.156 & & & 0.241 \\
\hline Adj. R Square & & & & 0.152 & & & 0.234 \\
\hline F - statistc & & & & 43.484 & & & 34.427 \\
\hline Sig & & & & 0.000 & & & 0.000 \\
\hline
\end{tabular}

Source: Statistic software result.

Remarks: The dependent variable is earnings management through the FEGL post (ABSEMFEGL).

$\mathrm{MML}=$ pressure on monetary liabilities, $\mathrm{OP}=$ condition of Operating Profit, $\mathrm{RP}=$ percentage increase (decrease) of Rupiah exchange rate against USD at the end of the year compared to the beginning of the year, it. TA per $1 \times 10^{6}=$ average total assets, $\mathrm{LEV}=$ ratio of total debt to average total assets, ROA $=$ ratio of net income to average total assets, $\mathrm{D} 1=$ dummy variable, $1=\mathrm{MML}>0, \mathrm{D} 2=$ dummy variable, $1=\mathrm{OP}<0$, D3 = dummy variable, $1=$ appreciation condition or IDR $>0, * * *=$ significant level at $1 \%$ level; $* *=$ significant level at $5 \%$; $*$ significant level at $10 \%$ 


\subsection{Discussion}

Empirical data was not supported to confirm the research hypothesis in rupiah depreciation. Companies in the gain position are more aggresive to do earnings management through the FEGL post compared to companies that are in a position of loss. In a depreciation condition, companies that have monetary liabilities in foreign currencies are smaller than the monetary assets of foreign currencies in a position of gain. Conversely, they are in a loss position when having monetary liabilities in foreign currencies that are greater than monetary assets in foreign currencies. In the financial statements, the monetary assets in foreign currencis were cash and cash equivalents and trade receivables, while the monetary liabilities in foreign currency were short-term loans, long-term loans, and others. When the company gets a loan, the company gets supervision from the lending institution. Supervision of lenders causes managers of companies with monetary liabilities in foreign currencies to be higher than monetary assets in foreign currencies performs earnings management less than companies that have smaller monetary liabilities in foreign currency than monetary assets in foreign currencies.

This research has supported the hypothesis that companies that are at a loss position are more aggresive to do earnings management by utilizing the FEGL post than companies that are at a position of gain. In a condition of appreciation, a company that is at a loss position is a company that has monetary liabilities in foreign currencies that are smaller than monetary assets. Companies that have monetary liabilities in foreign currencies that are smaller than monetary assets have lower covenant compliance and supervision of lending institutions, so they are more willing to manage earnings through the FEGL post. These empirical results confirm the Prospect Theory that the fundamental phenomenon of risky and uncertain choices is that losses appear to be higher than gains [20]. The more courageous act of making earnings management through the FEGL post was the act of looking for risk because the manager's opportunistic actions can be known by users of financial statements.

This research confirms the hypothesis that a company that is in a loss position due to a decrease in operating profit is more willing to do earnings management by utilizing the FEGL post compared to a company that is in a position of gain that has increased operating profit. This empirical evidence confirms Prospect Theory in the context of the operating profit situation. Companies that experience a decline in operating profit behave more bravely doing earnings management through the FEGL post. These results are in line with previous research; namely, when operational performance is inferior, some companies carry out a "big bath" strategy [18]. In contrast to Yoon \& Miller's research that measures operational performance using cash from operating activities, this study proves that the company carries out earnings management through the FEGL post.

\section{Conclusions}

This study aims to prove the existence of Prospect Theory in the context of earnings management, specifically earnings management in foreign currency transactions. The results of this study prove that on the condition of rupiah depreciation, company managers who are in a position of gain are more daring to do earnings management compared to managers who are in a position of loss. These empirical results contradict the research hypothesis based on the Prospect Theory that managers who are in a loss position will be more willing to manage earnings through FEGL than managers who are in a position of gain. This research succeeded in proving the existence of Prospect Theory under conditions of appreciation of the Rupiah and the decline in operating profit. In a condition of Rupiah appreciation, companies that are at a loss position because they have monetary liabilities of 
foreign currency are smaller than monetary assets of foreign currencies more daring to manage earnings through the FEGL post compared to companies that are in a position of gain that has more significant foreign currency monetary liabilities compared to monetary assets of foreign currencies. Companies that are in a position of loss due to a decline in operating profit compared to the previous year are more willing to do earnings management through the FEGL post compared to companies that are in a position of gain that has increased operating profit compared to the previous year.

Theoretically, this study provides the benefit of developing Prospect Theory in explaining the problems of earnings management behavior in conditions of monetary liability pressures both in terms of appreciation and depreciation of the Rupiah as well as operating profit pressures. Methodologically, this study proposes and successfully proves a new measurement model to detect earnings management through the FEGL post. Finally, the results of this study contribute to the accounting literature and accounting reporting policymakers, that earnings management can be done by utilizing the FEGL post.

This study has limitations, first, in terms of measuring earnings management variables through the FEGL post. To estimate a normal FEGL, the FEGL model requires consistency in the reporting currency. When a company changes its reporting currency in the period, the company is not included in the sample. Second, the revenue transaction variable in foreign currencies used to estimate the normal FEGL only comes from the export sales. Revenues in foreign currencies other than from export sales cannot be obtained in the notes to financial statements.

\section{References}

1. P.M. Healy, Journal of Accounting and Economics, 7(1-3):85-107(1985). http://dx.doi.org/10.1016/0165-4101(85)90029-1

2. R.J. Indjejikian, M. Matějka, K.A. Merchant, W.A.V. Stede, The Accounting Review, 89,4:1227-1258(2014). https://www.aaajournals.org/doi/abs/10.2308/accr-50732

3. Butt, U., Chamberlain, T., Sarkar, S. (2016). International Journal of Accounting and Finance, 6,3:167-196.

https://www.inderscienceonline.com/doi/abs/10.1504/IJAF.2016.081691

4. I.D. Dichev, D.J. Skinner, Journal of Accounting Research, 40,4:1091-1124(2002). https://onlinelibrary.wiley.com/doi/abs/10.1111/1475-679X.00083

5. A. Jha, Journal of Accounting, Auditing \& Finance, 28,4:369-396(2013). https://journals.sagepub.com/doi/abs/10.1177/0148558X13505597

6. Z. Tao, Asian Review of Accounting, 22,3:304-317(2014). https://www.emerald.com/insight/content/doi/10.1108/ARA-01-2014-0012/full/html

7. S.R. Stubben, The Accounting Review, 85,2:695-717(2010). http://www.aaajournals.org/doi/abs/10.2308/accr.2010.85.2.695

8. S. Roychowdhury, Journal of Accounting and Economics, 42,3:335-370(2006). https://www.sciencedirect.com/science/article/abs/pii/S0165410106000401

9. M.J. Ahearne, J.P. Boichuk, C.J. Chapman, T.J. Steenburgh, Journal of Accounting Research, 54,5:1233-1266(2016).

https://onlinelibrary.wiley.com/doi/abs/10.1111/1475-679X.12134

10. D. Herrmann, T. Inoue, W.B. Thomas, Journal of Accounting Research, 41,1,89108(2003). https://onlinelibrary.wiley.com/doi/abs/10.1111/1475-679X.00097

11. L.G. Eldenburg, K.A. Gunny, K.W. Hee, N. Soderstrom, The Accounting Review, 86,5:1605-1630(2011). http://www.aaajournals.org/doi/abs/10.2308/accr-10095

12. L. Hyun-Ah, C. Won-Wook, International Journal of Accounting \& Information Management, 24,2:162-184(2016).

https://www.emerald.com/insight/content/doi/10.1108/IJAIM-06-2015-0040/full/html 
13. D.A. Cohen, R. Mashruwala, T. Zach, The Use of Advertising Activities to Meet Earnings Benchmarks: Evidence from Monthly Data. AAA 2008 Financial Accounting and Reporting Section (FARS), NYU Working Paper No. 2451/27558, 141(2009). https://link.springer.com/article/10.1007/s11142-009-9105-8

14. C.J.O. Trejo-Pech, R.N. Weldon, M.A. Gunderson, Canadian Journal of Agricultural Economics/Revue, 64,1:89-118(2015).

https://onlinelibrary.wiley.com/doi/abs/10.1111/cjag.12063

15. L.B. Brian, S. Haeyoung, V. William, K.D. Wuk, Asian Review of Accounting, 25,1:58-84(2017). https://www.emerald.com/insight/content/doi/10.1108/ARA-092015-0091/full/html

16. S. Wasiuzzaman, I. Sahafzadeh, N.R. Nejad, Review of Accounting and Finance, 14,3:324-347(2015). https://www.emerald.com/insight/content/doi/10.1108/RAF-072014-0075/full/html

17. B. Jaggi, P. Lee, Journal of Accounting, Auditing \& Finance, 17:295-325(2002). https://journals.sagepub.com/doi/abs/10.1177/0148558X0201700402

18. S.S. Yoon, G.A. Miller, The International Journal of Accounting, 37,4:395412(2002).

https://www.sciencedirect.com/science/article/abs/pii/S0020706302001930

19. IAI. Standar Akuntansi Keuangan. [Financial Accounting Standards]. Jakarta: Dewan Standar Akuntansi Keuangan Ikatan Akuntan Indonesia(2016). https://www.academia.edu/download/56038731/ED-PSAK-69-07-Sept-20153.pdf

20. D. Kahneman, A. Tversky, Econometrica: Journal of the Econometric Society, 263291(1979). $\quad$ https://www.uzh.ch/cmsssl/suz/dam/jcr:00000000-64a0-5b1c-000000003b7ec704/10.05-kahneman-tversky-79.pdf

21. M.S. Bazaz, D.L. Senteney, American Journal of Business, 16,2:55-62(2001). https://www.emeraldinsight.com/doi/abs/10.1108/19355181200100012

22. F.D. Hsiao, L. Han, The International Journal of Business and Finance Research, 6,3,1-12(2012). https://papers.ssrn.com/sol3/papers.cfm?abstract_id=2094488

23. D. Burgstahler, M. Eames, Journal of Business Finance \& Accounting, 33,5-6:633652(2006). https://onlinelibrary.wiley.com/doi/abs/10.1111/j.1468-5957.2006.00630.x

24. D. Holland, A. Ramsay, Accounting \& Finance, 43,1:41-62(2003). https://onlinelibrary.wiley.com/doi/abs/10.1111/1467-629X.00082

25. M.L. Pududu, C. de Villiers, South African Journal of Economic and Management Sciences, 19:18-34(2016).

http://www.scielo.org.za/scielo.php?script=sci_arttext\&pid=S222234362016000100002

26. M.S. Norman, M.I. Takiah, M.R. Mohd, Malaysian Accounting review, 4,1:2538(2015). http://arionline.uitm.edu.my/ojs/index.php/MAR/article/view/319

27. K. Fujiyama, T. Kagaya, T. Suzuki, Y. Takahashi, Journal of Commerce and Management, 48,1:1-30(2014). https://www.jstor.org/stable/43295049

28. W.M. Trochim, J.P. Donnelly, Research Methods Knowledge Base, USA: Mason$\mathrm{OH}(2008)$.

base/oclc/811323127

https://www.worldcat.org/title/research-methods-knowledge- 